J OURNAL OF French and Francophone Philosophy
REV UE DE LA

philosophie française et de langue française

\title{
The Fecundity of Exile
}

\section{Albert Memmi}

Journal of French and Francophone Philosophy - Revue de la philosophie française et de langue française, Vol XIX, No 2 (2011) pp 4-6

\author{
Vol XIX, No 2 (2011) \\ ISSN 1936-6280 (print) \\ ISSN 2155-1162 (online) \\ DOI $10.5195 /$ jffp. 2011.504 \\ www.jffp.org
}

\section{(cc) EY-NC-ND}

This work is licensed under a Creative Commons Attribution-Noncommercial-No Derivative Works 3.0 United States License.

\section{ULIS D-Sunt}

This journal is operated by the University Library System of the University of Pittsburgh as part of its D-Scribe Digital Publishing Program, and is co-sponsored by the University of Pittsburgh Press 


\section{The Fecundity of Exile}

\section{Albert Memmi}

My dear Térésa, ${ }^{1}$

I am writing to you from a ship, which is to say from nowhere. Without luggage because at each call our luggage remains on board. That is why I love cruises.

Marseille, Venice, Athens, Haïfa, Valletta, Tunis: I have left each of these cities without regret, in the anticipation of seeing the next one.

Venice is no longer a city but a theatre. It is an imaginary city where even artisans work as standbys. There are glass blowers, book binders, and pattern makers, but no bakers or butchers. If I wanted to imagine a city, I could not have done better than the Story of Venice.

Athens: the kitsch and the dust around the Parthenon. Indeed, except for a few sites preserved by chance, does Greece exist? A rectangle delineated by stones is the Palace of Agamemnon, explains the enthusiastic guide, as if he were convinced of the fact. The gods should be flying around in the air everywhere, but one can never see them.

Valletta: I looked hard, but I did not find a relationship between the ghosts, which are the best tourist attraction here, and the actual inhabitants of the island. Warm and chubby, they are perhaps our former carriage coachmen who have returned from exile.

Haïfa: it will still take more time for this country to exist otherwise than in the Bible, or than in what pilgrims believe that they find there.

Tunis: the ill-assorted, which exists only in my memories. One must leave it to find a few walls washed white or blue, infinitely repeated.

There is not one of these cities, however, in which I could live.

I need to make a confession to you, which is costly: the suffering of exile has often been deplored, and I have had a share in this. It is time to add that exile is also fecund. 
As for myself, I have drawn great benefit from having four or five countries and not just a single one.

For forty years, longer than in my home country, I have lived in Paris, and I am in love with this city to the point that it seems to me the most beautiful city in the world. I speak and write in French; I even believe that I have ended up dreaming in French. French is my language as the free, reasonable and rational man that I strive to be. It is the language of the disciplined but fastidious citizen of a democratic country. It is the indispensible tool for my everyday work as a writer and teacher. French is my way of thinking the universal.

I could not possibly say all that Arabic has been for me, despite my immersion without return in French, especially after the death of my parents. For me, it remains the essential, the intimate familiarity with common roots in the Arab world, such that I rediscover myself in countries from Morocco to Syria.

Hebrew, the language of my childhood imagination, the language of the lived and narrated Bible, quoted with ease and naturalness in our circle of artisans, which our local Arabic with accomplices expressions. Today it is the language of a project of rejoining in an unexpected manner an almost mythical past with a political future.

Italian is a language that is music to my ears. I find great enjoyment in speaking Italian and in hearing my Italian friends say, with me learning from them, "Tesoro mio," "Carrissimo."

I will say nothing about a few bits of Maltese, which I picked up from being around my father. He was so well-versed in this surprising ArabChristian dialect that he was often taken to be Maltese. Not to mention the fossilized Spanish, spoken with the distinction of Cervantes, to the point that linguists, it seems, came to study among the Jewish families that had taken refuge here since the inquisition. Nor to mention Greek, the idiom of the philosophers, which I was professionally until literature prevailed over it.

The other side of exile, finally, is to enjoy multiple affiliations and especially to acquire from them a sense of indulgence toward everyone. Groups require us to be this or that, because groups are large beasts without brains. They are jealous because they are afraid. The truth, increasingly, is that we are both this and that, and even more. I would like to have five passports while waiting to have them all.

In short, dear Térésa, I write to your from nowhere, which is to say from everywhere.

In the meantime, with love. 
1 Translated with permission by Scott Davidson from the French original, “Fécundités de l'exil" in Histoires de lecture (Lire en Fête, 2003). 